\title{
"A Desora Desperto y vio una Grand Claridat": The Role of Dreams and Light in the Construction of a Multi-Confessional Audience of the Miracles of the Virgin of Guadalupe
}

\author{
Amanda Valdés Sánchez ${ }^{(D)}$ \\ Humanities Department, Universitat Pompeu Fabra, 08005 Barcelona, Spain; amanda.valdes@upf.edu
}

Received: 31 August 2019; Accepted: 7 November 2019; Published: 29 November 2019

\begin{abstract}
This paper examines the religious proselytizing agenda of the order of Saint Jerome that ruled the Extremaduran sanctuary of the Virgin of Guadalupe since 1389. To this end, I analyze how the Hieronymite's used literary motifs such as dreams and light in the codex of the Miracles of the Virgin of Guadalupe to create a multi-confessional audience for their collection of miracles. I contend that these motifs were chosen because they were key elements in the construction of a particular image of the Virgin that could appeal to pilgrims of different faiths. Through them, the Hieronymites evoked in the minds of Muslim pilgrims and Christian captives beyond the sea the imagery and rhetoric of Sufi devotional literature and Islamic hagiography, in order to create a vision of the Virgin that was able to compete with the more important Islamic devotional figures: the Prophet, Sufi masters and charismatic saints. Finally, I explore how the possible influence of North African devotional models, such as the Shadhiliyya order or the hagiography of the Tunisian saint, Aisha al-Manubiyya, suggests that the aims of the monastic authors of this Marian miracles collection went far beyond the conversion of Castilian Muslims, aiming at the transformation of the Extremaduran Marian sanctuary of Guadalupe into a Mediterranean devotional center.
\end{abstract}

Keywords: dreams; light; miracles; Virgin; religious proselytism; conversion; Sufism; Castile; North Africa; captives

\section{Introduction}

Sometime in the 15th century, a young North African woman of Muslim origin arrived at the town of Guadalupe in Extremadura in order to serve the monastery of the Virgin of Guadalupe, for whose devotion she had made such a long journey. There is documentary evidence that confirms the existence of this "convert", known as "la buena christiana," who received some benefits from the monastery (Rubio 1926, p. 219) and seems to have owned houses in the town and collaborated with the inquisition by donating land (De Écija 1953, p. 345). To preserve her memory, the monastic community recorded her story in a series of codices collecting the miracles of the Virgin of Guadalupe (Anonymous n.d.c, Codex C2, BMG, 15th C., p. 233r). By the end of the 16th century, her tomb had been installed inside the church and covered by a marble headstone in which the pilgrims could read the story of her miraculous conversion at the hands of the Virgin of Guadalupe (De Talavera 1597, p. 233r). Conversion stories such as the one of "la buena christiana," based or not on real events, used for preaching in the monastery church or as an edifying reading among pilgrims (Crémoux 2001), were intended to function as a reminder of the miraculous abilities of the Virgin and as a role model for the Castilian Mudejar subjects.

Since its origins, the sanctuary of the Virgin of Guadalupe was linked to the repopulation and Christianization of the Castilian colonial lands in the south of the Iberian Peninsula. The cult of the Virgin of Extremadura had its origin in the miraculous apparition of a Marian image before a shepherd, 
Gil Cordero, in the early 14th century, in the mountains of Villuercas near the town of Guadalupe, in the province of Cáceres. The story of the apparition of the Extremaduran image was one of the many legends emerging across southern Iberian lands, in which Marian images appeared in rural settings to individuals of humble origins, such as shepherds, peasants and artisans. The diffusion of these kinds of narratives disseminated a Christian notion of the miraculous and helped develop a new sacred geography that characterized the religious imaginary of the southern territories. These stories of Marian apparitions and miraculous images promoted the popularization of new southern Marian cults during the 14th and 15th centuries that, for the first time, extended beyond regional boundaries. This is the case of the cults of the Virgen del Rocío of Almonte, the Virgen de la Cabeza of Andújar and the Extremaduran Virgin of Guadalupe, which succeeded thanks to their ability to address the spiritual needs of the diverse popular classes of the South. From the mid-1320s, the Castilian crown was interested in promoting the Extremaduran sanctuary of the Virgin of Guadalupe. (Linehan 1985; De Paula Cañas Gálvez 2012). Between 1335 and 1338 and with the support of the king and the blessing of Pope Benedict XII, Cardinal Don Pedro Gómez Barroso built a church dedicated to the cult of the Virgin of Guadalupe, replacing the primitive hermitage (Pérez de Tudela 1982, p. 273). During these years, Alfonso XI (1312-1350) extended his protection to the Extremaduran sanctuary, granting between 1337 and 1388 no less than 54 privileges designed to provide the monastery with a solid economy based on agricultural and livestock exploitation (Filomena 1983, pp. 125-27; Llopis Agelán 1998, pp. 423-24; Vizuete Mendoza 1980). During the reigns of Peter I (1350-1366), Henry II (1366-1379) and John I (1379-1390), the Castilian Crown kept the Extremaduran monastery under its protection, founding new chaplaincies (Vizuete Mendoza 1988, p. 294), defending the sanctuary against its adversaries and creditors (Díaz Martín 1982), improving the conditions of pilgrimage roads, and protecting the monastery's alms collectors (De Paula Cañas Gálvez 2012, p. 433). Royal support for the Guadalupe sanctuary favored its progressive transformation into the new religious center of Castile. Its miraculous image was able to attract equally romeros and new settlers from northern Castile to the unpopulated areas of Extremadura and the Guadalquivir valley, exploiting the connections established through the grazing of the Mesta in the network of ravines that converged in Extremadura (Linehan 1985, pp. 297-300, 303).This "repopulating" strategy, initiated by Alphonso the Wise through his promotion of the emerging sanctuaries of the South, such as the Monastery of Saint Genesius of Jara or the new Marian churches of Our Lady of El Puerto, Tundía or Terena, was based on the consolidation of a new form of popular religiosity linked to rural life, romerias, and the sacralization of the land (Llopis Agelán 1998, p. 424).

In 1389, the Extremaduran sanctuary passed into the hands of the Order of Saint Jerome, a young order closely linked to the Castilian monarchy and nobility (Campos y Fernández de Sevilla 2008). The two founders of the Castilian branch of the order, Pedro Fernández Pecha and Fernando Yánez de Figueroa, had served in the court of Alfonso XI and Peter I (Revuelta Somalo 1982). Many members of the order belonged to the Castilian nobility (Highfield 1983; Revuelta Somalo 1982; Llopis Agelán 1998). The order enjoyed the patronage of the Trastámara dynasty and of some aristocratic families, like the Mendozas (Nader 1979). The royal patronage of the order responded to the Crown's desire to transform it into the main instrument of its religious policies, placing the order in charge of important new foundations in the principal cities of Castile and in the newly conquered settlements of the South (Ruiz Hernando 1997). In the interest of favoring the development of the new Hieronymite house in Extremadura, the Castilian monarchy, from the reign of Juan II until the Catholic Monarchs, granted new privileges to the monastery. The Crown appointed the Hieronymites feudal lords of the village of Guadalupe (Bernal 1978, pp. 31-33), supported the development of their livestock economy, and authorized Guadalupe's alms collectors to travel freely across the land (Llopis Agelán 1998, pp. 424-25). In order to increase the popularity and fame of the miraculous Marian image they had inherited, the Hieronymites compiled the collection of miracles of the Virgin of Guadalupe that is the focus of this article. The collection had its origin in the miraculous stories that pilgrims said had motivated their trip to the monastery, which were collected by a monk who interviewed the pilgrims. These first 
notes were written down in a longer version and recorded in a complete collection of all the miracles told by the pilgrims during the 15th century (Díaz Tena 2007, pp. 89-90). Four manuscripts survive that contain stories of events that are supposed to have happened in the 15th century: the codices $\mathrm{C} 1$, C2, C3 and C4 (Anonymous n.d.c), held in the monastery's library. The compilers of the final version of the miracles of the Virgin of Guadalupe aspired to shape the experience of the visitors during their stay in the monastery and their relationship with the Virgin of Guadalupe after their departure by exalting her ability to assist her devotees in all sorts of trouble (Crémoux 2015, pp. 24-26).

The present study is part of a scholarly effort that seeks to rethink the development of the genre of Marian miracula in the multi-confessional context of medieval Castile. Most analysis has focused on how the genre was related to the Castilian colonizing project of the former Andalusian territory, especially evident in the miracle tales in which the Virgin achieved the conversion of Jews and Muslims on the Peninsula and overseas. For instance, Amy Remensnyder has drawn attention to the proselytizing agenda of these stories in Castilian collections such as the Cantigas de Santa Maria or the 16th century version of the Milagros de la Virgen de Guadalupe (Remensnyder 2014). Likewise, Francisco Prado-Vilar has explored the evidences of religious accommodation in the representation of the Virgin in the tales of Marian conversion (Prado-Vilar 2005). Similarly, my research follows the work of Alexandra Cuffel, who has pointed out the symbolic relationship of the Peninsula and the Maghreb in these stories and their instrumentalization of shared cults in the former al-Andalus and North Africa (Cuffel 2003, 2005). This paper also interrogates the relationship between the production of the Extremaduran Marian miracle collection and the emergence between the 14th and the 15th centuries of a Castilian devotional literature equally shaped by European devotional trends, religious polemic, and contacts with the Castilian Muslim population. As Cynthia Robinson and Gerard Wiegers have suggested, these relationships produced the particularities of Castilian Lives of the Virgin, such as the ones written by Francesc Eiximenis and Juan Lopez de Salamanca (Robinson 2013; Wiegers 1994). Finally, my research explores the medieval origins of the deliberate use of Marian devotion as a proselytizing tool, which Felipe Pereda has observed regarding the evangelization of the first moriscos of Granada (Pereda 2007).

\section{Dreaming with the Virgin}

Throughout the different codices, the compilers of the miracles of the Virgin of Guadalupe collected stories in which the Virgin sought the conversion of Muslims from North Africa and the kingdom of Granada. These locations represented the two frontiers of late medieval Castilian monarchy: the military and spiritual conquest of North Africa and the remains of al-Andalus, both in the kingdom of Granada and within the Mudejar population that lived inside the kingdom. After the main Castilian military victories over al-Andalus in the 13th century, the Castilian monarchs imagined the conquest of North Africa as an extension of the "Reconquista" enterprise, which would allow them to recover the former territory of the Roman province of Hispania, the Hispania Tingitana or Transfetana. This desire is evident in the policies of Ferdinand III (1217-1252) after the conquest of Seville in the African Crusade of Alphonso X the Wise, in the treaty of Monteagudo (1291) in which Sancho IV (1284-1295) and James II of Aragon (1285-1302) divided the North African territory between the two Hispanic crowns, and in the confrontation between Alfonso XI and the Marinids in the battle of El Salado (De Bunes Ibarra 1995). This ambition, propelled by the struggle against North African privateers, the demands of Andalusian merchants, the crusade mentality and, after 1492, by the surrender of Granada, (Braudel 1928; Hess 1978), led to the conquest of the Canary Islands (1478) and the port city of Melilla (1497). The interest in North Africa is also clear in the Hieronymite miracles of the Virgin of Guadalupe. Of the 21 conversion miracles recorded in the four codices collections, nine are located at the other side of the Strait ${ }^{1}$ and some of these stories, like the conversion of Ali and Fatima, were

1 See Codex 1, fol. 145v, 155v; Codex 2, fol. 92r, 126r; Codex 3, fol. 5r, 68v, 97v, 102r, 164r. 
recorded multiple times and transformed into symbols of the evangelical abilities of the Extremaduran Virgin. ${ }^{2}$

The 15th century, especially during the reign of Henry IV (1454-1474), also witnessed the reemergence of the interest in the religious practices and beliefs of the Mudéjar population among the Castilian elites. This is evident, for example, in the presence of copies of the Latin translation of the Breviario Sunni of the Mudejar religious leader of Segovia, Yça Gedelli (d. after 1462), in Castilian noble and ecclesiastic libraries, in the correspondence between Yça Gedelli and the theologian John of Segovia (d.1458), or in the polemical response of Juan López of Salamanca (d.1479) to the Islamic treatise of the Segovian alfaqui (Wiegers 1994, pp. 134-42; Rouhi 2005, Robinson 2013, pp. 209-11). Recent studies have identified several circumstances that fueled this interest: the presence of a significant number of Muslims or former Muslims in the court as part of the Moorish King's Guard, the debate generated by the supposed favoritism of king Henry IV toward his Mudéjar subjects (Echevarría Arsuaga 2006), the development of a "pacific" model of conversion by John of Segovia and Nicholas of Cusa (d.1464) (Cabanelas Rodríguez 2007), the campaign against the Nasrid kingdom of Granada (Echevarría Arsuaga 1999), and the project of the evangelization of the Moorish population of Granada led by Fray Hernando de Talavera (d.1507) (Pereda 2007).This proselytizing attitude is also clear in the miracles of the Virgin of Guadalupe. Not only did this collection include more conversion miracles than previous Castilian Marian miracle collections, it also offered a new vision of the process by which Muslims embraced Christianity following the guidance of Mary. While, in some of the Alphonsian cantigas, Muslim characters received the Virgin's miraculous assistance without losing their faith and the Wise King recognize and even exploit the Islamic veneration of Maryam, ${ }^{3}$ in the codices of the miracles of the Virgin of Guadalupe the memory of the Islamic cult to Maryam has been erased. In the Extremaduran collection, the Muslim protagonists of conversion miracles are initiated by Christian characters into Marian devotion as something foreign to their former faith, and the development of their devotion to Mary marked irrevocably their final conversion.

The proselytizing nature of these conversion stories can also be seen in the didactic manner by which Christian captives try to introduce their Muslim captors to the Catholic faith (Rodríguez 2010). One of these miracles tells how Rodrigo, a captive "allende del mar," [beyond the sea] explains to his Muslim master the role of religious images, the Trinity and the creed. ${ }^{4}$ In another miracle, a cleric held captive by a Muslim king says Mass at the request of his captor, who even provides him with everything required to offer the service. ${ }^{5}$ Another characteristic of these stories is the goodwill with which Muslim protagonists receive the evangelical message, as in the case of Ali, who receives complete instruction in the principles of the Christian faith and the wonders of the Virgin of Guadalupe, first from his Christian wife and secondly from an Ethiopian monk whom he had known in Jerusalem. ${ }^{6}$

2 The story of Ali was copied twice, once in the first codex $(\mathrm{C} 1$, fol.145v) and once in the third codex $(\mathrm{C} 3, \mathrm{fol}$. $97 \mathrm{v})$.

3 See CSM 165, 169, 185, 215, 329.

4 "E dijole el moro: "Rodrigo muy locos soys los xianos ". E dixo el xiano: "Señor por q aquello", dixo el moro su señor: "teneys muchos dioses, ca tenys a ihu x, a dios, y a todos llamays dioses, ca adoraes muchas ymagenes". E el xano le respondyo: "Señor no vos maravilledes q solo nro señor ihu xo tiene sesenta u tres nombres. E si adoramoa a las ymagenes adoramoslas endereçado nra señora y fe a dios padre, e fijo e spiritu santo un solo dios verdadero en essentia q crio el cierlo y la tierra y nros seño ihu xto creemos ser" (Codex C3, BMG, Miracle 5, fol. 5r).

5 "E demandole el rey q cosa era missa. E el clérigo le dixo q le fiziesse traer las cosas necesarias pa ella y el la diría ante el ... E el clérigo fecho su altar revistiose delante del rey y començo su confesión .... E el clérigo faziendo su officio de la myssa rogo por el rey y por todos qntos ally estaban y fueron todos convertidos a la verdadera creentia y baptizados con el rey por manos del clérigo". (Codex C3, BMG, Miracles 5, fol. 8v).

6 "Por lo cual preguntó Halí qué cossa era esta santa María de Guadalupe. Al qual su mujer le respondió que era una casa sancta de devoción a do sancta María, Madre de Jhesú Christo, Dios de los Christianos, era dellos avida en especial reverençia e devoción, que se llamava de Guadalupe. E fablando con él algunas cosas de las que los christianos creen, tráxolo e tanto que le prometió ir a la santa çibdad de Jherusalén para se informar más complidamente de la verdad de la sancta fe. ( ... ) E allí estovo con un monje negro etiopiano, de tierra de preste Juan de Indias, el qual por entonces estaba en el sancto sepulcro e le enseñó las letras caldeas, porque en saber estas cosas Halí era muy curioso e solíçito e allegado mucho a razón. E aquel monje, por los miraglos que oía decir de sancta María de Guadalupe, propuso venir a la visitar a España"(Codex C1, BMG, Miracle 167, fol. 144r-145v). 
In several miracles, the compilers use the motif of dreams to express the Virgin's desire to favor conversion. The Virgin of Guadalupe appears to future converts, showing them the path of Christian revelation. In the story of Ali, for example, after considering converting and fleeing with his wife to Christian territory, he dedicates a prayer to the Virgin of Guadalupe and then receives a vision of her in his dreams:

... And, Our Lady having received his full devotion, she gave him a sign of the effect of his request, because the following night he dreamed that he was in a big palace filled with a great light and that a very beautiful queen, dressed in blue, with a white tabard over her, was sitting on a throne. And he saw that many young men dressed in white entered through the door of the palace and bowed before the queen who was sitting on the throne. And [one of them] told him that she was the Virgin Mary, to whom he had commended himself.

In this way, when he woke up, finding in himself a renewed devotion, he understood that he had not been deceived in his pious dream and he commended himself again [to the Virgin] with an even greater desire to be baptized in the Christian faith. (Codex C1, BMG, 145r-145v)

[E, reçibiendo Nuestra Señora su buena devoción, diole señal del efecto de la su petición, porque la noche siguiente le pareçió en sueños que estava en un grand palacio lleno de grand claridad e que estava asentada en él en una silla muy fermosa una reina vestida de azul e un tabardo blanco encima. E vido que entrava por la puerta de aquel palacio e salían por otra muchos mançebos vestidos de blanco e fazían reverençia a aquella reina que estava asentada en la silla. E díxole que aquella era la Virgen María, a quien él se avía encomendado.

Pues que así es, despertando e fallando en sí nuevo movimiento de devoción, entendió non ser engañado en el su piadoso sueño e tornó con de cabo a se recomendar con mayor deseo de reçebir la fe de christiano en el baptismo.]

The use of dreams as a vehicle of spiritual awakening, like the one experienced by Ali, has important biblical precedents, such as the divine revelations in dreams received by the prophets Abraham, Jacob, Joshua in the Old Testament, or the dreams through which Christian truth is revealed to the Wise Men or to the wife of Pontius Pilate in the New Testament (Koet 2009). Ali's dream also evoked the visions of heaven present in the Bible (Daniel 7.9-10) and in medieval Castilian literature (Montero 2010). Since Antiquity, divinely inspired dream visions and revelatory dreams were presented in Christian dreambooks, patristic writings, and saints' lives as a way of contacting God or achieving transcendent knowledge or a spiritual experience (Kruger 1992; Lynch 2004). Dreams also played an important role in Christian conversion stories from Saint Agustin's Confessions to medieval Iberian accounts of conversion to Christianity, such as the writings of Alfonso of Valladolid (d.1346) or Juan of Avignon (d.1418) (Szpiech 2013). This association between dreams and conversion was reinforced by the writings of missionaries, including Jacques of Vitry (d.1240/1244), who asserted that many Muslims "have been warned in their dreams by Jesus Christ or by the blessed Virgin or by some saint that they should cross over from the Muhammadan error to the grace of Christ". (Huygens and Vitry 1960, p. 88; Tolan 2002, pp. 199-200). As in Ali's story, in many Christian dream accounts the Virgin was represented as a dreamlike provider of spiritual illumination, like the oneiric apparition of the Virgin to St. Bernard. This image of the Virgin is equally present in Marian miracle collections, including Castilian examples such as the Milagros de Nuestra Señora of Gonzalo de Berceo ${ }^{7}$ and the Cantigas de Santa Maria of Alfonso the Wise ${ }^{8}$ (Garrosa Resina 1987; Montoya Martínez 1981). In these works, Mary's apparition to her devotees frequently occur in dreams, leading, in some cases, such as the one

7 See Miracles of Our Lady, Poem III, X, XIX, XXII, XXV.

8 See Cantigas de Santa María, 15, 79, 85, 285, 309, 345, 348, 384. 
of the famous monk Theophilus, to their conversion or spiritual renewal. This topos also appears in conversion miracles, as the one narrated in the cantiga 85, as in which the Virgin appears in dreams to a captive Jew, freeing him and showing him the wonders of Heaven and Hell.

For a Muslim audience, Ali's story could also evoke the Islamic conception of dreams as a means to communicate with the sacred. Islamic religious tradition understood dreams as a fundamental means of divine revelation (Green 2003). Not only did the Quran and numerous hadiths affirm the role of dreams in the revelation of God's message to Muhammad (Sirriyeh 2015), but Muslims were also encouraged to perceive dreams as openings to what is not apparent through the senses or understandable by the intellect (Ohlander 2012). In the Sufi tradition, dreams were understood as a means to achieve the mystical experience, obtain visions of the other world (Sirriyeh 2015, p. 58), or receive spiritual guidance from the Prophet and deceased masters (Sirriyeh 2015, p. 140). This epistemic function of dreams is especially clear in the case of visions in dreams or $r u^{\prime} y \bar{a}^{9}{ }^{9}$ understood as the way in which divinity placed ideas in the minds of devotees while they sleep. This is the case of the oneiric revelation received by Ali, in which a heavenly vision of the Virgin invited him, in a symbolic way, to join the Christian ranks. The way in which Ali received in dreams a revelation as an answer to his concerns also resembled the Sufi practice of istikhāra ${ }^{10}$ or incubation, in which, after the recitation of a prayer and the pronunciation of a formula of supplication, the faithful sought a dream in which the answer would be revealed (Ohlander 2012, p. 204). This similarity is reinforced by how the protagonist of this miracle uses the dream to make a transcendental decision, seeking the answer of which path he should take in divine inspiration, as in Sufi practice (Katz 2012, p. 194).

Ali's dream also referred to the function of dreams in spiritual initiation, typical of the Sufi imaginary. Similar to the initiatory visions that the 12th century Persian Sufi master Rūzbihān al-Baqlī (d.1209) described in his book, The Unveiling of Secrets, the vision Ali received combined highly symbolic content with images of courtly imagery (Ernst 1996, pp. 56-57). This miracle also reflected a conception of dreams as a vehicle for experiencing visions of heaven, similarly to that narrated by the 11th century Persian Sufi master Shams al-Din al-Daylami (d.1037). In his writings, this Sufi

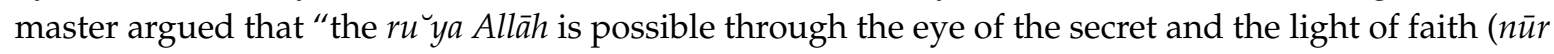
al-īmann) before death, in this world, because God may grant privilege (fadl) to whomsoever of His servants" (Alexandrin 2012, p. 224). Al-Daylami suggested that if spiritual beings like angels appeared in dreams, it was a revealed vision and not a product of human imagination (Alexandrin 2012, p. 220). According to these parameters, Ali's vision would have seemed to be true to an islamic audience.

The role of the dream in the definitive conversion of Ali also would have evoked the function of dreams in the spiritual education of Sufi teachers or saints in biographical dictionaries (tabaqat), certain hagiographies (manāqib), and spiritual autobiographies. As in al-Futuhat al-Makkiyya of the 13th century Murcian Sufi master Ibn 'Arabi (d.1240), dreams often marked not only the initial spiritual conversion of the protagonist but also the different stages on his way to enlightenment (Halligan 2001, p. 285; Corbin 2014, p. 273). Since in these accounts Sufi neophytes frequently received visions of the Prophet or their deceased masters, attributing this role to the Virgin of Guadalupe in her miracles

9 "Ru' $y \bar{a}$, derived from the Semitic root $r-^{\prime}-y$ which gives rise to formations expressing "sight" $\left(r u^{\prime} y a(t)\right)$ and "vision" $\left(r u^{\prime} y \bar{a}\right)$, one of the aspects of vision being nocturnal vision, the dream. Concerned to distinguish the true dream, rendered by $r u^{\prime} y \bar{a}$, from the false dream, resulting from the passions and preoccupations of the soul, or furthermore the dream inspired by God from that inspired by Satan. [The $r u^{\prime} y \bar{a}$ is] the point of concurrence between the nocturnal vision or dream and the prophetic vision (diurnal and nocturnal) or ecstasy" (Bosworth et al. 1995, vol. VIII, p. 645).

10 "Istikhāra, deriving from a root kh-y-r which expresses the idea of option or choice, consists of entrusting God with the choice between two or more possible options, either through piety and submission to His will, or else through the inability to decide oneself, on account of not knowing which choice is the most advantageous one. To the first category belong the $a k h y \bar{a} r$ or "chosen", who regulate their lives according to the model inspired by God in the Kur'an and the Law; to the second belong the mustakhirūn, those who seek to escape from indecision with the help of divine inspiration. The divine voice expresses itself either by means of a $r u^{\prime} y \bar{a}$ [q.v.] or dream, or else by kur'a [q.v.] or rhapsodomancy ... This orthodox practice is generally interpreted in a sense which makes it comparable with incubation. After the invocation, the formulae for which are of different kinds and varying in length, the devotee goes to sleep, and it is in a dream that the revelation is made to him" (Lewis et al. 1978, vol. IV, p. 259). 
reaffirmed her religious authority to other possible converts. In a similar way, the use of this motif in the Guadalupe miracles exploited the role of dreams in the personal stories of conversion to Islam that circulated in the polemical literature, in which, as in Ali's story, two fundamental elements influenced the final decision - the rational search for the true faith and the divine inspiration received in dreams (García-Arenal 2001; Smilansky 2008).

In the same way, the Virgin's ability to appear in the dreams of her devotees replicated the abilities not only of Christian saints (Bitel 1991; Miller 1994; Moreira 2000; Lynch 2004), but also of contemporary North African Islamic saints (Sirriyeh 2015, p. 172; Katz 1992) whose cult also had a popular vocation and was based on the exaltation of their "charismatic" qualities. As in the hagiography of these saints, such as the Tunisian Sufi Aisha al-Manubiyya, the Virgin of Guadalupe appeared in dreams to her faithful after an invocation, working through this apparition a miracle that satisfies their requests. ${ }^{11}$ This parallelism is especially significant because the saint, like the Virgin of Guadalupe, used dreams in her miracle stories to convert some of her followers to the ascetic path. In one of her miracles, for example, the saint appeared in the form of a vision or $r u^{\prime} y a$ to one of her followers, who sought spiritual guidance among the saints of the necropolis of Manuba in northern Tunisia:

I turned around and saw Sayyidatî ‘Āisha al-Manûbiyya-may God be pleased with her ... She said to me: "Do not move [from your place] but remove from your heart any attachment to the world below. I knew she was one of the Friends of God-exalted be He. "

I asked him, "What is the best remedy for this?"

"The death of the senses," she said, "externally and internally; and fear of God deep within your heart and in your outer behavior".

He says: "By God, from that day on, there was no room in my heart for this world, and I received great advantage from her observations and her words. I often invoked God through her mediation and all my wishes were fulfilled through her baraka-may God be pleased with her and grant us merit for her blessings, here below and in the afterlife". (Amri 2008, pp. 215-16)

“Je me retournai et aperçus Sayyidatî 'Âisha al-Manûbiyya—Dieu l'agreé ... Elle me dit: «Ne bouge pas [de ta place] mais abolis de ton cœur l'attachement au monde d'ici-bas. Je sus qu'elle partie des Amis de Dieu—exalté soit-il.»

Je lui demandai: «Quel este le meilleur remède pour cela?»"

«La mort des sens, dit-elle, extérieurement et intérieurement; et crains Dieu dans le secret de ton cœur et dans ton comportement extérieur.»

II dit: “Par Dieu, a dater de ce jour, il n'y eut plus de place dans mon coeur pour ce bas-monde et je tirai grand profit de son regard el de sa parole; j'invoquais souvent Dieu par sa médiation et tous mes vœux étaient exauces grâce à sa baraka—puisse Dieu être satisfait d'elle et nous faire crédit de ses bénédictions, ici-bas et dans l'au-de la,"

Like the hagiography of the Tunisian saint, the miracles of the Virgin of Guadalupe evidenced a conception of the miraculous, typical of contemporary North African Sufi literature, which gave greater importance to the inner transformation of the faithful and the role of miracles in their spiritual education (Sánchez Sandoval 2004, p. 99).

11 See examples in (Amri 2008, pp. 191, 198, 205-7, 219, 227, 236, 239). 


\section{The Marian Enlightenment}

Another characteristic of the image of the Virgin of Guadalupe in the miracles is her luminous nature, appearing, in many of them, before her faithful as a shining vision, dressed in white, whose light filled the room. ${ }^{12}$ In the story of Fatima, "la buena christiana", Mary was seen in this way:

And a wonderful thing happened that one night while she was sleeping and one of her aunts was sleeping in another bed near hers: she woke up and saw a great light over the bed in which the Moor (her aunt) was laying, which shone as if more than a thousand candles were burning, even more than the sun, and it lasted for two hours. (Codex C2, BMG, 99r)

E acaecio una cosa maravillosa que yasiendo ella una noche durmiendo, una su tia que en otra cama cerca de ella dormia, a desora despertó y vio una grand claridat sobre la cama en q yasia la mora, la qual resplandecia mucho más q quanto mil velas pudiesen ally estar encendidas y aun mas q el sol y duro assy por espacio de dos oras.

As Rachael Fulton has recently pointed out, the luminous conception of the Virgin was a prominent theme in medieval Marian devotional literature. It frequently appeared as a metaphor for Mary's reception of divine wisdom and grace in hymns, litanies, and psalters composed in her praise, as well as in contemplative treatises that were widely diffused across Europe, such as the Speculum seu salutatio beatae Mariae virginis of the Franciscan Conrad of Saxony (d.1279), the De laudibus beatae Mariae virginis, of the Rouen canon Richard of Saint-Laurent (d.1250), the Mariale sive liber de praecellentibus et eximiss SS. Dei genitricis Mariae of the Franciscan preacher Servasanctus of Faenza (d.1300) or the Pseudo-Albertus Magnus Mariale (Fulton Brown 2019). In his text, Conrad of Saxony explained how Mary's mind had been filled with the light of wisdom even before the conception of Jesus and how, as the Psalms proclaimed, her mind was so shaped by the contemplation of God that her face shone, reflecting the divine wisdom infused into her (Alcántara Martínez 1975, pp. 270-71). As a result, Mary not only had perfect knowledge of the Incarnation, the Trinity, her own predestination, of souls, angels, and demons, of the scriptures and the creation, as Pseudo Albert affirmed (Borgnet 1898, pp. 167-68), but she also had the graces of healing, working miracles, prophecy, discernment of spirits, and the interpretation of scriptures (Fulton Brown 2019, p. 82).

This conception of the Virgin as a recipient and source of divine revelation was also popular in Castilian devotional literature. According to a contemporary Castilian psaltery (Anonymous n.d.a, Salterio de la Virgen, BNE Mss. 9533, 9541, fragments in Mss. 6326, 6539 y 276), the face of the Virgin emanates a light so bright that it was scarcely bearable and it led her devotees to mystical ecstasy. Likewise, a 14th century Marian devotional book that belonged to the Cathedral of Avila, the Mariale sive de laudibus Beatae Virginis Mariae (Anonymous n.d.b, BNE Mss. 8952), which has been identified as a Castilian version of the work of Servasanctus of Faenza (Fulton Brown 2019), depicted the Virgin as a source of light whose luminosity symbolized her ability to illuminate and transform the hearts of her devotees. This image of the Virgen was also typical of Marian miracle collections. In the Cantigas de Santa María, Mary appears many times to her devotees as a luminous entity. ${ }^{13}$ In some cases, the shining nature of the Virgin was linked to conversion miracles. In cantiga 192, the Virgin appears "come lumẽeira" [like a lamp] to a Muslim captive locked up by his master in a cave, finally convincing him to accept the baptismal sacrament. The image of Mary as illuminatrix of the world was also popularized in Castile by Hispanic accounts of the life of the Virgin produced between the end of the 14th and mid-15th centuries, like the Vita Christi of Francesc Eiximenis (d.1409) or the Vida de la

12 Codex C1 miracles 1, 2, 19, 31, 35, 36, 37, 39, 41, 43, 45, 51, 55, 70, 74, 82, 100, 101, 113, 124, 129, 144, 149, 151, 152, 156, 160, 166, 167, 175, 194, 197, 203, 206, 209, 211, 224, 227, 237, 244; Codex C2 miracles 52, 92, 96, 111, 112, 117, 122; Codex C3 miracles 4 , 5, 6, 10, 37, 43, 63, 71, 94, 106, 110, 118, 119, 128; Codex C4 miracles 5, 18, 26, 48, 75, 76, 89, 139.

13 See CSM 36, 49, 69, 89, 91, 121, 134, 192, 261, 313. 
Virgen of Juan Lopez of Salamanca (d.1479), according to which her illuminated nature was testimony to a life full of arrebatamientos (raptures) and mystical experiences.

As Cynthia Robinson has pointed out (Robinson 2011), in the multi-confessional Castilian context, the alumbrada condition of the image of the Virgin presented in these devotional works would have evoked in the minds of a possible Mudejar audience the luminous character of the Prophet in the aljamiado text, Libro de las luces (Lugo Acevedo 1999), as well as the prophetic abilities that the Andalusian Islamic tradition attributed to Maryam (Fierro Bello 2002). This is especially true in cases such as the ones of Eiximenis or Lopez of Salamanca, whose works were shaped by their polemical and proselytizing agenda. Certainly, this glowing image of the Virgin could evoke, to a Muslim audience, the Islamic conception of Maryam as a source of light. A hadith related by al-Walid ibn Muslim, for example, represented Maryam as a source of physical and spiritual light, identifying her grave as the source of a radiant light noticed by the Prophet (Schleifer 1998, p. 73). This luminous conception of Maryam also derived from a vision of her life marked by her privileged access to divine revelation and was present in works such as that of the Persian mystic Rūzbihān al-Baqlī. According to this mystic "[Maryam] was trained by "the Real," by the light of intimacy ... And the Illumination of the 'witnessing of the Eternal' shone upon her. And when she experienced the vision of the Illumination of the Manifestation of Eternity, Its Lights flashed, and Its Secrets reached her spirit, and her spirit became impregnated with the Divine Secret, and she became the bearer of the glorious word and the light of the spirit of the Most High" (cited in Schleifer 1998, p. 92).

The diffusion of the image of the Virgin as a source of light in Castilian literature could also refer to a luminous conception of divinity, typical of the Islamic mystical tradition, associated with a vision of ecstasy as the act in which the divine light passes through the heart of the mystic. This understanding of light appears in the writings of one of the most representative Sufi teachers of the Shadhili School, the Andalusian Ibn Abbad al-Rundi (d.1390):

Then God Most High singles out certain of His servants by manifesting Himself to them through His light, something that is most evident to them. They travel by that light along the way that their intimate knowledge of Him indicates most clearly ... He frees them from slavery to sensible knowledge and causes them to die to all other things ... [This path] rests on the light of certitude, by which only the Clear Truth is manifest. That is the most sublime thing that can descend from the heavens into the hearts of chosen believers ... (Al-Rundī 1986, pp. 61-62)

In one of the miracles, the protagonist, a captive Christian woman, witnessed a radiant apparition of the Virgin of Guadalupe after a series of spiritual exercises. She subsequently underwent a mystical experience similar to that described by the Sufi mystics of the Shadhili tariqa, induced, in this case, by a luminous Virgin of Guadalupe who, after the mystical encounter, showed her servant the road to freedom:

And, being one night in this devout prayer, I saw a great brightness coming down from the sky like a star and it stood close to me and seemed to be moving and casting rays of light at me. And looking at it I was very amazed and said: Madam, are you the glorious Virgin of Guadalupe to whom I have commended myself? And as I said these words many times, Our Lady visibly appeared to me very beautiful and bright ... (Codex C1, BMG, 40v)

E, estando yo una noche en esta devota oración, vide descender del cielo una claridad muy grande a manera de estrella e pusosse cerca de mí e pareciome que se movía e lançaba rayos de claridad contra mí. E yo, mirándola fui mucho maravillada e dixe: Señora, ¿eres tú la Virgen gloriosa de Guadalupe a quien yo me he encomendado? E como yo estas palabras dixesse muchas vezes, apariciome visiblemente Nuestra Señora muy fermosa e resplandeciente... 
This conception of the Virgin also appears in the aforementioned 15th century Spanish Mariale in which Mary, as in the miracles of the Virgin of Guadalupe, is presented to her devotees as a means for their spiritual ascent through a progressive process of inner transformation similar to the one Sufi mystics sought. ${ }^{14}$ At the end of their arduous spiritual journey, what awaits the devotees of Mary was inner peace and quietude, a reward that, as Cynthia Robinson observes, could be equally appealing for Muslims seeking divine illumination (Robinson 2013, pp. 191-92).

The luminous presentation of the Virgin in the Guadalupe miracles also recalls the modes of legitimation found in Sufi hagiographies of women saints. Like the Tunisian saint Aisha al-Mannubiya, the Virgin of Guadalupe is presented as God's chosen one. Aisha's privileged reception of mystical truth rivaled that of the Prophet, and also emanated to the outside world through her baraka or miraculous abilities. It implied to her faithful that, after entrusting themselves to her or visiting her grave, she would assist them in their moments of greatest adversity:

I am 'Aisha al-Mannûbiyya, blessed be the one who visits me, calls upon me in adversity, seeks refuge at my grave, comes to me and speaks to me (...) I am a security for everyone who visits me and relies upon me in adversity. I am the Lady of Spiritual Men ... (Amri 2008, pp. 166-67)

Je suis 'Aisha al-Mannûbiyya, bienheureux celui qui me rend visite, me sollicite dans l'adversité, se recuille sur ma tombe, vient à moi et me parle (... ) Je suis une sécurité pour quinconque me visite et s'en remet à moi dans l'adversité. Je suis la Dame des hommes spirituels ...

In the miracles of conversion, both the Virgin of Guadalupe and Aisha acted as an extension of divine revelation capable of generating a transformation within their faithful, "enlightening them".

Since, in the Islamic literary tradition, dreams played a fundamental role in legitimizing the level of mystical knowledge attained by Sufi masters (Jones 2003, p. 126; Sirry 2010), the Virgin of Guadalupe's appearance in the dreams of Muslim converts reaffirmed the authority of these converts to function as spiritual models among their former co-religionists or other possible converts. A clear example is the case of Fatima, "la buena christiana", the young woman from Tangier inspired to convert to Christianity for her devotion to the Virgin of Guadalupe. The spiritual journey of Fatima shows everything that the Church demanded of every "good Christian": the practice of daily prayers, ${ }^{15}$

14 “Domina illuminatio mea sit splendor facie tue, et serenitas gratie tue refulgeat menti mee ( ... ) Dominus regit me, virgo dei genitrix, quia tu amabilem vultum eius firme convertisti. Benedicti sint splendidissimi occuli tui, quos dignaris misericorditer convertere super peccatores. Benedictum sit lumen et splendor facie tue, benedicta sit gratia vultus tui. Benedicta sit misericordia manuum tuarum, benedicta sit emanatio virginei lactis tui. Benedicant te aplí et pphe dei, rores confessores et virgines psallant tibi" (BNE Ms. 8952, 72r-73v) [“Our Lady, illuminate me with your brilliant face and your serene grace reflected in my mind (... ) The Lord guides me, Virgin Mother of God, because you turned your loving face toward him. Blessed be your most splendid eyes, which you mercifully deign to turn upon sinners. Blessed be the light and splendor of your face; blessed be the grace of your countenance. Blessed be the mercy of your hands; blessed be the flowing of your virginal milk. Apostles and God's prophets bless you; martyrs and confessors offer psalms to you" (Robinson 2013, pp. 419 , note 161).

15 "Ca leuantándose de mañana fyncaua las rodillas en tierra e ofrescía al Sennor tres veces el pater noster a reuerencia de la Santa Trinidat, e nueve veces el aue maría a la gloriosa Virgen María nuestra Sennora, e asy fasía en la noche quando se quería acotar a dormir, suplicándole con muchos sospiros que en breue le cumpliesse su santo deseo" (Codex C2, Miracle 92, fol. 99r). 
religious fasts, ${ }_{16}^{16}$ devotion to the Virgin, ${ }^{17}$ and devotion to the Passion. ${ }^{18}$ The religious education Fatima received from the Christian captives of her household exhibited the main practices and devotions that characterized the popular religiosity of Castilian southern colonial lands (Sánchez Herrero 1989). However, we can also recognize in this the legitimizing strategies of the sanctity of contemporary North African saints (Amri 2015; Chodkiewicz 1995), such as the aforementioned Aisha al-Mannubiya. Fatima, like other Muslim saints, such Aisha al-Manubiyya, ${ }^{19}$ is shaped according to the example of the Virgin Mary. Like Aisha's miraculous abilities, ${ }^{20}$ the mercy and compassion of the good Christian are presented as innate ${ }^{21}$ and, again like the Tunisian saint, ${ }^{22}$ Fatima seems to have been chosen by God and endowed with an exceptional spiritual ability among her fellow human beings. ${ }^{23}$ While Aisha had received al-Khidr's visit in her youth, ${ }^{24}$ Fatima received the vision of the Virgin of Guadalupe in dreams. ${ }^{25}$ Finally, as with Aisha al-Mannubiyya ${ }^{26}$ and the Virgin in the Castilian devotional literature (Robinson 2013), "la buena christiana" received her knowledge of the Christian doctrine directly from God, ${ }^{27}$ presenting herself as Mary and Aisha as an alumbrada. Through these sources, the miracles

16 "E como ella preguntase al dicho xpiano Peres por que no avia querido comer carne en tal dia pues que los otros xpianos lo hacia, el le respondio que lo fasia por reverencia de la pasión de ihu xpo nuestro señor que ental dia la avia recibido por redempcion del mundo. Ella tan grand devoción conabio en su corazón que desde aquel dia propuso de nunca comer carne en viernes. E como oyesse otrosy que los xpianos non acostumbraban comer carne en la cuaresma ella quando buenamente podía no la comia en aquel tiempo. Pero por quanto del todo non lo podía assy guardar por no ser barrutada de sus parientes a los menos guardaba se de no comer carne los miércoles, viernes, y sábado de la cuaresma y fingiendo a las veces que le dolia la cabeza o las muelas, a las veces el vientre" (Codex C2, Miracle 92, fol. 98r).

17 "E commo fuesse otrosypreguntada qué nonbre quería, e algunos le dixessen que se llamase María, respondió con mucha humildat que ella non era digna nin merescía tal nonbre, nin era razón que la syruienta ouiesse el nonbre de la sennora" (Codex C2, Miracle 92, fol. 103v).

18 “E por reverencia de la pasión del señor quando ella estaba en Tanjar nunca quería cantar el dia del viernes, segundo que primeramente acostumbrava a faseren señal y compasión del crucificado no quería peynarse ni lavar su cabeza. Pues como ella aprendiose de los xpianos captivos a faser la señal de la cruz cuando comía apartada de los moros fasia primeramente la señal de la cruz sobre la vianda que avia de comer" (Codex C2, Miracle 92, fol. 98r).

19 «J'ai hérité de Marie-paix sur elle-trois traits: le premier, la parole divine: «Car Die gratifie qui il veut sans compter [Cor:III:37]; le deuxieme, cet autre verset: «O Marie d'où cela te vient-il ? Cela vient de Dieu, dit-elle» [III:37] et le troisième ce propos de Die-exaltè soit-Il: «Lors les anges dirent: «Marie, Dieu t'a élue et t’a purifiée: Il t'a élue sur les femes des univers» [III:42]» (Amri 2008, La sainte de Tunis, pp. 165-66).

20 «On rapporte que lorsque Sayyidatî (ma dame) 'Âisha al-Manûbiyya était encore dans le sein de sa mère, elle réalisa quatre-vingts prodiges dont on fit l'expérience et dont furent témoins quarante maîtres parme les savants» (Amri 2008, p. 158).

21 "Pues que allí es esta mora ayudaba a encerrar algunas noches los captivos con la qual desde su niñez recibió la piedad del vientre de su madre salio conella que avia mucha compasión de la aflicion que pasavan los captivos a los quales fasia quanto bien podía" (Codex C2, Miracle 92, fol. 97r).

22 «Dieu m'a aimée; Il m'a choisie; Il m’a élue. Il m’a parée, abreuvée et sostenue. Dieu fait de moi la parure des saints, le Pôle des pôles» (Amri 2008, p. 161).

23 "E por ende nuestro señor dios padre de mas acatando a las limosnas y obras caritativas que con los xpianos aquesta mora fasia y conociendo el fervor de su corazón y la pureza de la su santa enteción con que lo fasia y la devoción que del avia, quiso aver de ella piedad llamándola a la suya fe, escogiéndola entre tantos millares de infieles asy como rosa entre las espinas" (CodexC2, Miracle 92, fol. 99v).

24 «On rapporte qu'âgée de douze et, alors qu'elle errait dans les rues de Mannûba, elle fut abordée par al-Khadir-paix soit sur lui-sous l'aspect d'une jeune homme» (Amri 2008, p. 159).

25 "E acaecio una cosa maravillosa que yasiendo ella una noche durmiendo, una su tia que en otra cama cerca de ella dormia, a desora despertó y vio una grand claridat sobre la cama en q yasia la mora, la qual resplandecia mucho mas q quanto mil velas pudiesen ally estar encendidas y aun mas q el sol y duro assy por espacio de dos oras. E la tia en este estado asy estaba espavorida que temblaba como asustada, ca no osava de levantarse y no podía hablar por el espanto que avia de tan gran claridat como veya. E otro dia dijo la tia aquesta visión a la dicha mora y a su madre ... la moca oyéndolo sintío luego en su corazón muy grand alegría que creya que era señal de la (iglesia?) de Ihu Xto que en su corazón avia el señor infundido" (Codex C2, Miracle 92, fol. 99r).

26 “Cornard, va! Cést Die qui m’a appris le Coran: Mikâyil et al-Khadir sont venus à moi portant un bocal rempli d'un breuvage paradisiaque et $\mathrm{m}$ 'on dit: «Bois, ô ' $\bar{A}$ 'isha al-Mannūbiyya», par cette boisson, je fût abreuvée de science, de longanimité, de certitude, de recueillement, d'humilité, de baraka, de tendresse du cœur, de chasteté et de préservation" (Amri 2008, Ibíd., p. 164-65).

27 “Demandando con grand sustancia y fervor el santo baptismo. Pues como ella fuese preguntada por los clérigos que al su baptismo estaban presentes de las cosas que pertenecen a nuestra fe según es costumbre ella alumbrada del espíritu santo respondia tan complacida y abiertamente como si luengo tiempo en la santa fe fuera adoctrinada" (Codex C2, Miracle 92, fol. 103v). 
of the Virgin of Guadalupe codified the "holiness" of Fatima according to the parameters of Sufi devotional literature.

\section{From Redemption to Conversion in Guadalupe and the Magreb}

Throughout the collection of miracles, the proselytizing vocation emerges not only in the miracles of conversion, but also in those concerning the liberation of Christian captives in the Islamic territories of the Peninsula and North Africa, before whom the Virgin also appeared as a dreamlike and luminous vision. Thus she appeared, as told in the miracles, to Juan Gutierrez, a man from Antequera, who was captive in the Nasrid kingdom:

One night, when he was sleeping in the stocks, he heard a voice in the air that told him: "What are you doing here, get out and go away, for you are not well". And as he remembered with fear the sound of that voice, he saw the house lit up as if it were the middle of the day, which comforted him, making him understand that it was the work of the Lord and his blessed Mother. And being joyful for that vision he commended himself again to our Lady ... Once he had said his prayer and made his vow, that night the same light he had seen before appeared and he heard the same voice that told him again: "What are you doing here, get out and go away". (Codex C2, BMG, 131r)

Pues q assi estando una noche en su cepo durmiendo, oyo una vos en el ayre q le dixo: "Que fases aquí, sal y vete q mal estas". E como recordase espantado del sonido de aquellas vos vio la casa tan clara como sy en medio del día fuera de qual mucho consolado y entendio q era obra de nro señor y de la su bendita madre y muy gososo de aquesta visión tornose a recomendar a nra señora ... E fecha su oración con la promesa de su voto vio esa noche aquella mesma claridat que de antes había visto y oyo la vos que le torno a desir: "Que fases aqui, sal y vete".

The stories that narrate how the Virgin appeared to her devotees in captivity as a luminous dream vision freeing and leading them to Christian lands were also typical of the Marian miracle collections produced in and beyond the Iberian Peninsula. In cantiga 325, a young Christian woman from the Extremaduran village of Tudía, who had been taken captive and imprisoned in Tangiers, received, in dreams, the apparition of the Virgin, who made her appear miraculously on her way back home after she woke up. Both of these characteristics were also typical of contemporary stories of Marian apparitions that, as William Christian as pointed out, were proliferating across the southern territories of Castile (Christian 1990). One example of this can be found in later records of the apparition of Mary and the celestial court that was supposed to take place in Jaen in 1430. According to one of the witnesses, he was sleeping at midnight when he was awakened by a light:

And he affirms that he thought that it was already daytime because there was a lot of light and that he got up naked and opened the door a little bit, and that he looked outside through the door ... and he saw five crosses one after another as they usually come in procession, and they were brought by five young men ... And that at the end of the procession of crosses there was a lady dressed in white... and that so much light came out of this lady that she shone like the sunlight at its clearest, and in this way she made the whole street visible. (Christian 1990, p. 58)

E que este firma que pensaba que era ya de día a tanto vido la claridad e que se levanto desnudo e abrió la puerta un poco, e que estuvo mirando de dentro de casa e la cabeza fuera para mirar por entre la puerta y la pared ... E que vido cinco cruces una tras otra como sueles venir en procesión, e que las traían cinco omes mancebos... E que en fin de la procesión de las cruces iba una dueña vestida cobijada con ropas blancas ... E que salía desta dueña tanta claridad que resplandescía así como el día resplandece quando hace sol claro e está en su virtud, e así que se veía toda la calle. 
Although this image of the Virgin was part of Castilian devotional culture, the representation of the Virgin of Guadalupe as a luminous dream vision could also endow her with the spiritual abilities of the Prophet, Sufi mystics, or the charismatic saints that dominated the religiosity of the Islamic territories where Christian captives were imprisoned. This duality of meanings seems to have generated a natural suspicion towards the Virgin's oneiric appearances. In one of the miracles, a Christian captive, Juan de Cifuentes, told his cellmate Gil de Genova of his encounter with the Virgin in dreams, who then advised him to be careful because such beliefs were prohibited by their faith:

And, as he recalled another day, he said to his companion: "You don't know how I saw Our Lady in dreams tonight and she gave me hope to expect the freedom we want, and truly I tell you that she told me that very soon we would be in her house where we promised to go", and hearing such things Gil de Genova said: "I believe she is powerful and that she could be able to do whatever she wants. But don't tell me that you saw her in dreams, because I don't believe it: we shouldn't believe in such things, because it is forbidden by our faith". (Codex C3, BMG, 145v)

E, como otro día recordó, dixo a su conpañero: "No sabes cómo he visto esta noche en sueños a nra señora e me dio su esperança con que esperace la libertad que deseamos, y en verdad más te digo, que me dixo que muy presto seríamos en su casa do prometimos, las qles cosas como Gil de Genova oyesse dixo: 'Creo yo ser poderosa y que podrá lo que quisiere. Empero dezirme que la viste en sueños no lo creo, porque non hemos de creer enllos, pues nos es vedado segund nra fe'"'.

This suggests that by using the devotional motifs of dream and light in the collection of miracles, the Hieronymites also sought to claim the attention of captive Christians, tempted, perhaps, to abandon their faith for the spiritual benefits offered by Sufi saints and masters. Significantly, in many miracles, the Virgin appears to her captive devotee when he or she is being pressured by his or her jailor to convert or when one of his or her fellow prisoners is finally persuaded to convert to Islam.

The interpretation I have made of the miracles of the Virgin of Guadalupe in relation to contemporary Sufi literature is in line with the interpretation that Cynthia Robinson has proposed of the so-called Mudejar cloister, also carried out under the Hieronymite government of the sanctuary. Throughout the 15th century, this cloister was completed with the placement of several fountains that marked the ritual space where many of the ceremonies dedicated to pilgrims took place (Andrés 2001, pp. 111-18). In this sense, Robinson has proposed that the inclusion of this series of fountains was designed to give a mystical sense to the experience of walking through the Guadalupe cloister. To this end, Robinson posits that this itinerary could have reminded the Muslim pilgrims of the way in which Sufi devotional texts such as the 14th-century Sufi treatise, The Book of Certainty (Al-Din 2010), imagined the spiritual journey of the disciples. It would have been a physical ascension through different levels and in which different fountains functioned as mirrors of the soul of the mystic, reflecting, in turn, different levels of knowledge of the divine (Robinson 2013, p. 142). For that matter, the fountain as a metaphor for the spiritual state of the mystic's heart was also present in the writings of Ibn 'Arabi (d.1240) (Asín Palacios 1990, p. 487) and Ramón Llull (d.1315-1316) (Hatzfeld 1955) and it persisted in Spanish mystical literature until the Siglo de Oro, as reflected in the works of San Juan de la Cruz (d.1591) (López-Baralt 1981, pp. 54-55).

For Christian pilgrims, the fountain may also have symbolized Mary's ability to initiate neophytes in the Christian faith and to serve as a guide on this ascending journey. Since Late Antiquity, patristic exegesis had identified the Virgin with the sealed fountain of the Song of Songs, emerging in the texts of St. Jerome and St. Ambrose as a figure not only of Mary's virginity but also of her immaculate conception (Twomey 2019). In the cloister of Guadalupe, formed by a garden centered by a fountain under a temple, different Marian symbols were superimposed: the closed garden, the sealed fountain and the temple of the Song of Songs, all metaphors of Mary's purity and divine gifts. The writings of St. Ambrose describe the sealed fountain as a means for washing sins away and attributes to it the ability 
to reflect God's image, endowing the Marian symbol with a salvific dimension. This salvific function of the Marian fountain was also present in late medieval Hispanic devotional poetry. In one poem, the Marquess of Santillana, Iñigo López de Mendoza (d.1458), called the Virgin "fontana de salvación" (fountain of salvation) (Pérez Priego and Santillana 1983, p. 277) and in another poem, composed during his pilgrimage to the Extremaduran monastery of the Virgin of Guadalupe, he described her as a "fontana de agua bendita" (fountain of holy water) (Pérez Priego and Santillana 1983, p. 279). Hence, the Marian fountains of Guadalupe could have been perceived as a place of spiritual renewal or religious initiation.

In late medieval literature, the Marian sealed fountain served as a metaphor for the Virgin's ability to reflect the divine light, making accessible divine wisdom through her beneficial waters (Twomey 2019, p. 170). In his Libro de la vida de Ihesu Christo (BNE INC-1126), Francesc Eiximenis described how the Virgin had received various mystical experiences in which she "[was] altered in herself" and was "very wonderfully illuminated and excited by God, our Lord." (Robinson 2013, p. 177). In her condition as enlightened, the Virgin was simultaneously a receiver and a source of illumination. In a chapter titled, "Que tal fue aquel preñado dela gloriosa y que bienes alcanzo ella del dicho concebimiento" [How was the pregnancy of the glorious lady and which gifts she received from this conception], Eiximenis reflects upon the biblical denominator "mater agnicionis" (Mother of Knowledge) of Ecclesiasticus 24:24: "que quiere dezir que ella es madre y fuente y abismo del soberano conoscimiento después de dios", which means that "she is mother and (a) source of great knowledge after God" (BNE INC-1126, 74r). In chapter XXI of the aforementioned 14th century Castilian Mariale (Anonymous n.d.b, BNE Mss. 8952), the author compared Mary with a fountain, listing the benefits derived from the waters of the Marian fountain: "Nothing could be more flavorful to the thirsting soul than a cool fountain such as this, with cold water for the thirsting soul" [dico quod anime vehementissime sitienti nichil ita sit sapidum ut fans frigidus secundum illud, aqua frigida anime sitienti, BNE Mss. 8952, fol. 44r]. In this way, the Mariale affirms to its readers that the waters of the Marian fountain offered them "a direct path to the kingdom of God" ["vias rectas usque ad regnum dei"]. The fountains located in the monastic cloister of Guadalupe could thus function not only as metaphors for the Virgin, but also as symbols of her condition as a transmitter of divine knowledge.

The proselytizing purpose of these fountains is also suggested by the fact that in the Islamic religious imaginary fountains were associated with the Quranic story that narrated the epiphany and conversion of the Queen of Sheba (Surah 27.15-47). The promise of spiritual enlightenment offered by the fountains of the cloister of Guadalupe could be due to a similar aim, fueled by an ecstatic conception of religious conversion present in works such as the Book of the Gentile and the Three Wise Men (Llibre del Gentil e los tres savis) of Ramón Llull (Hames 1999).

\section{Conclusions}

I do not wish to argue that these motifs have their origin in Islamic tradition; rather, although they belonged to the Christian tradition as well, Castilian Christians chose them because they could appeal to a potential Muslim audience and because they enabled them to invest the Extremaduran Virgin with a religious authority constructed according to the parameters of Islamic religious tradition. This does not mean that they could not be read or interpreted by Christian pilgrims from their own religious tradition. This paper has sought to demonstrate that the election of these motifs to represent the Virgin of Guadalupe before a multi-confessional audience could have been motivated by their association with both religious traditions and their ability to attract pilgrims of different faiths. Indeed, the fact that these motifs were used in the Muslim and Christian traditions with similar meanings allowed the inventors of the miracles of the Virgin of Guadalupe to address a multi-confessional audience by disseminating a common message of Marian spiritual guidance and protection. For these reasons, these motifs appear consistently in the miracles linked to the conversion of Muslims and to the liberation of Christian captives in Islamic territory, two cases where both faiths interact with each other. This is especially relevant when we consider the particular characteristics of the Iberian context, marked not 
only by the daily interaction of the two religious traditions but also by the familiarity with the beliefs of neighboring faiths, the existence of shared devotions and religious festivities, and the tension between proselytizing and polemical attitudes.

Yet how could the authors of the miracles of the Virgin of Guadalupe have known about the use of dreams and light in Sufi devotional literature? One of the key avenues could have been through the works of the Murcian mystic Ibn 'Arabi. His writings also portrayed a mystical and legitimizing understanding of dreams (Corbin 2014, p. 213; Chittick 1989, p. 22; Halligan 2001; Ibn 'Arabi 1980, pp. 13, 45). He also provides a conception of a feminine incarnation of divine theophany (Corbin 2014, p. 196), Sophia, represented as a nocturnal and luminous presence that appears to the mystic to "enlighten him" on his path, abandoning him when he wakes up (Corbin 2014, pp. 196, 326-27). Similarly, in his work, Ibn 'Arabi recognized the spiritual capacity of women (Chodkiewicz 1989, p. 127) through the exaltation of Maryam as the paradigm of the mystic (Corbin 2014, pp. 194-95), through the symbolic character of the beautiful Nizam (Ibn 'Arabi 2008, p. 36) and through his teachers, Shams of Marchena de los Olivos and Fatima of Córdoba whose beauty and spiritual purity functioned as a suitable vehicle for attaining knowledge of God (Ibn 'Arabi 2008, pp. 25-26). The work of Ibn'Arabi was very influential in the Islamic world, including in the Iberian Peninsula (Knysh 1999, pp. 167-200; Chodkiewicz 1991, pp. 36-57) and his work seems to have influenced even some Christian authors, like the Franciscan missioner Ramon Llull (Urvoy 1980; Garcías Palou 1981; Maíllo Salgado 1992; Roque 2008), whose work was prominent in the library of the Extremaduran monastery and one of the main influences in Hieronymite spirituality (Vizuete Mendoza 1986). Nonetheless, given the diffusion that the work of Ibn' Arabi seems to have had we should consider to what extent the compilers of the miracle collection could have known of this motifs and its meaning in Islamic mysticism simply through oral transmission or through its influence in the polemic or devotional literature of local mudejar population. Certainly, some of the more relevant aljamiado works preserved suggest that these motifs had a long live among Mudejar communities (Lugo Acevedo 1999; Narváez Córdova 2001; Vázquez 2016).

Another vehicle of transmission of these motifs could have been the Shadhili order of Sufis on the Peninsula, which seems to have been influential among the Iberian Muslims, as evidenced by the work of Ibn Abbad al-Rundi (Honerkamp 2005, 2009). The Shadhili influence could also be the means by which the life of the Tunisian saint Aisha al-Manubiyya reached the Peninsula since she claimed to be one of the disciples of Abu al-Hasan ash-Shadhili, the founder of this tariqa, to whom she aspired to be a spiritual disciple (Kugle 2007, pp. 113-15). Although it is difficult to identify the particular way in which this hagiography reached the Peninsula, the relevance of this work increases the probability that it was known on the other side of the Strait as a relevant model for the configuration of the sanctity of the Virgin of Guadalupe. After all, the biography of this saint, composed in the 14th century by an anonymous imam of the Manuba Mosque, is the only example of manâqib literature dedicated to a North African female saint in medieval times (Amri 2000, 2010).

The parallels between the work of Ibn 'Arabi, the devotional discourse of the Shadhili order, and the life and miracles of Aisha al-Mannubiya with the codices of the Miracles of the Virgin of Guadalupe evince how the Hieronymite collection aspired to appeal to a multi-confessional audience by exploiting the motifs and topoi of popular Islamic religious literature, like other Castilian contemporary devotional productions (Prado-Vilar 2005; Robinson 2013). In this way, the Virgin of Guadalupe, like the Virgin of the Alphonsine Cantigas, was bestowed by her creators with the main elements of Sufi Andalusian popular religiosity in order to appeal to the diverse audiences that characterized Castilian cities and villages, in the North as well as in the South. The diffusion of these kinds of miraculous stories served in this way to consolidate the emerging identity of Christian Castilian settlers in the South and to assimilate the Mudejar religious minority in a time of increasing confessionalization in Castilian society (Rodríguez 2013). But the inclusion in the miracles of the devotional language of the Shadhili tariqa or the spiritual qualities of the Tunisian female saint also points to the use of North African devotional models in the creation of the image of the Virgin of Guadalupe. This fact could 
indicate an intentional exploitation by the Hieronymites of the religious authority that North African religious leaders had among the Castilian Mudejars, but it is also relevant due to the prominence of North African Muslim characters in the conversion stories recorded in the Extremaduran collection (Rodríguez 2010).

It would be interesting to interrogate to what extent the attribution to the Virgin of Guadalupe of the characteristics of Maghrebi devotional figures in the many stories in which she favored the conversion of North African Muslim characters reflected the methods of Christian missionaries who worked among the North African populations or the expansion of the colonial ambitions of the Castilian Crown beyond the Mediterranean Sea. Moreover, the representation of the Virgin of Guadalupe in this way in the stories in which Christian characters kept captive by North African masters were saved and comforted by her in times of spiritual crisis could have been intended not only to appease the anxieties of Castilian Christians towards captivity and religious deviation. Such stories would also have buttressed the faith of those men and women captive beyond the sea, whom the wonderful stories of the Virgin's miracles were supposed to have reached. In this sense, the use of North African devotional models such as the Tunisian saint Aisha al-Manubiyya in the characterization of the Virgin of Guadalupe may have served to transform the Extremaduran sanctuary into a Mediterranean devotional center and the Virgin of Guadalupe into a potent devotional figure capable of attracting devotees from the Castilian aljamas, the Nasrid kingdom of Granada, and even, as was the case of Fátima, from the other side of the Strait.

Funding: This paper is the result of my PhD research funded by the Fellowship Program of "La Caixa" Foundation (ID 100010434), with code LCF/BQ/DE17/11600020.

Conflicts of Interest: The author declares no conflict of interest.

\section{References}

\section{Primary Sources}

Anonymous. n.d.a. Salterio de la Virgen (BNE Mss 9533, 9541, fragments in Mss. 6326, 6539 y 276).

Anonymous. n.d.b. Mariale sive de laudibus Beatae Virginis Mariae. 14thCentury. Ávila: Castile, (BNE Mss. 8952).

Anonymous. n.d.c. Codices C1, C2, C3 and C4. Library of the Monastery of the Virgin of Guadalupe, Cáceres, Extremadura.

De Talavera, Gabriel. 1597. In Historia de Nuestra Señora de Guadalupe: consagrada a la soberana magestad de la Reyna de las Angeles milagrosa patrona de este sanctuario. En Toledo: en casa de Thomas de Guzman. Biblioteca de Castilla-La Mancha (Mss.565). Toledo: en casa de Thomas de Guzman.

Eiximenis, Françes. n.d. Libro de la vida de Ihesu Christo. Granada: p. 1496, (BNE INC-1126).

\section{Secondary Sources}

Alcántara Martínez, Pedro. 1975. Speculum seu Salutatio Beatae Mariae Virginis ac Sermones Mariani. Rome: Bibliotheca Franciscana Ascetica Medii Aevi II.

Al-Din, Siraj. 2010. Book of Certainty: The Sufi Doctrine of Faith, Vision and Gnosis. Cambridge: Islamic Texts Society. Alexandrin, Elizabeth R. 2012. Witnessing the Lights of the Heavenly Dominion. Dreams, Visions and the Mystical Exegeses of Shams al-Din al-Daylami. In Dreams and Visions in Islamic Societies. Edited by Ozgen Felek and Alexander D. Knysh. New York: State University of New York Press, pp. 215-31.

Al-Rundī, Ibn Abbad. 1986. Ibn 'Abbād of Ronda: Letters on the Sufi Path. Edited by John Renard. New York and Mahwah: Paulist Press.

Amri, Nelly. 2000. Les sâlihât du Ve au IXe siècle/XIe-XVe siècle dans la mémoire maghrébine de la sainteté à travers quatre documents hagiographiques. Al-Qantara. Revista de Estudios Arabes 21: 481-509. [CrossRef]

Amri, Nelly. 2008. La Sainte de Tunis. Présentation et traduction de l'hagiographie de 'Aisha al-Mannūbiyya. Collection «La Bibliothèque de l'islam». Arles: Sindbad. 
Amri, Nelly. 2010. Entre hagiographie, hagiologie et histoire: La place des femmes dans le soufisme à travers quelques sources du Maghreb médiéval. In Graines de Lumière. Héritages du cheikh al-'Alawî. Edited by Ahmad Al-Alawi. Paris: Editions Albouraq, pp. 398-424.

Amri, Nelly. 2015. Entre Orient et Occident musulmans: Retour sur la sainteté féminine (IIIe/IXe siècle-fin du IXe/XVe siècle): Modèles, formes de l'ascèse et réception. In Figures de Sainteté Féminine, Musulmane et Chrétienne, en Afrique du nord et au Proche-Orient: Actes du Colloque International Organisé par le Centre d'études et d'interprétation du fait Religieux de la Faculté des sciences Religieuses. February 20-21. Beirut: 1'Université Saint-Joseph (Beyrouth), pp. 13-86.

Andrés, Patricia. 2001. Guadalupe, un Centro Histórico de Desarrollo Artístico y Cultural. Salamanca: Diputación de Cáceres, Institución Cultural El Broncense.

Asín Palacios, Miguel. 1990. El Islam Cristianizado: Estudio del "sufismo" a través de las obras de Abenarabi de Murcia. Madrid: Hiperion.

Bernal, Tomás. 1978. Guadalupe en la leyenda y en el primer período de su historia. In Guadalupe: Historia, Devoción y Arte. Edited by Sebastián García and Felipe Trenado. Seville: Editorial Católica Española, pp. 19-70.

Bitel, Lisa M. 1991. 'In Visu Noctis': Dreams in European Hagiography and Histories, 450-900. History of Religions 31: 39-59. [CrossRef]

Borgnet, A., ed. 1898. Beatus Albertus Magnus. In Opera Omnia. Paris: Ludovicus Vivès, vol. 37.

Bosworth, Edmund Clifford, Emeri Johannes Vandonzel, Wolfhart P. Heinrichs, and Gérard Lecomte, eds. 1995. Encyclopedia of Islam. Leiden: Brill, vol. 8.

Braudel, Fernand. 1928. Les espagnols et l'Afrique du Nord de 1492 a 1577. Revue Africaine 69: 184-233, 351-428. Cabanelas Rodríguez, Darío. 2007. Juan de Segovia y el Problema Islámico. Granada: Universidad de Granada.

Campos y Fernández de Sevilla, F. Javier. 2008. Los Reyes de España y la Orden de San Jerónimo en los siglos XV-XVI. In Carlos V en Yuste. Muerte y Gloria Eterna. Catalogue of the Exhibition Celebrated at the Yuste Monastery in 2008. Madrid: Patrimonio Nacional, pp. 113-43.

Chittick, William C. 1989. The Sufi Path of Knowledge: Ibn al-Arabi's Metaphysics of Imagination. Albany: State University of New York Press.

Chodkiewicz, Michel. 1989. Le Sceau des Saints. Sainteté et Prophétie dans la Doctrine d'Ibn 'Arabî. Paris: Gallimard.

Chodkiewicz, Michel. 1991. The Diffusion of Ibn 'Arabi's Doctrine. Journal of the Muhyiddin Ibn 'Arabi Society 9: 36-57.

Chodkiewicz, Michel. 1995. La sainteté féminine dans l'hagiographie islamique. In Saints Orientaux. Edited by Denise Aigle. Paris: De Boccard, pp. 99-115.

Christian, William A. 1990. Apariciones en Castilla y Cataluña: Siglos XIV-XVI. Madrid: Editorial Nerea.

Corbin, Henry. 2014. Creative Imagination in the Sufism of Ibn Arabi. Princeton: Princeton University Press.

Crémoux, Françoise. 2001. Pèlerinages et Miracles à Guadalupe au XVIe Siècle. Madrid: Casa de Velázquez.

Crémoux, Françoise. 2015. Las Edades de lo Sagrado: Los Milagros de Nuestra Señora de Guadalupe y sus Reescrituras. Zaragoza: Institución Fernando el Católico (CSIC), Diputación de Zaragoza.

Cuffel, Alexandra. 2003. 'Henceforth All Generations Will Call Me Blessed': Medieval Christian Tales of Non-Christian Marian Veneration. Mediterranean Studies 12: 37-60.

Cuffel, Alexandra. 2005. From Practice to Polemic: Shared Saints and Festivals as 'Women's Religion' in the Medieval Mediterranean. Bulletin of the School of Oriental and African Studies 68: 401-19. [CrossRef]

De Bunes Ibarra, Miguel Ángel. 1995. La presencia española en el norte de África: las diversas justificaciones de las conquistas en el Magreb. Aldaba 25: 13-34. [CrossRef]

De Écija, Diego. 1953. Libro de la Invención de esta Santa Imagen de Guadalupe y de la Erección y Fundación de este Monasterio y de Algunas cosas Particulares y Vidas de Algunos Religiosos de él. Edited by Angel Barrado Manzano. Cáceres: Publications of the Provincial Department of Seminaries (FET) and of the Councils of National-Syndicalist Offensive (JONS).

De Paula Cañas Gálvez, Francisco. 2012. Devoción Mariana y poder regio: las visitas reales al monasterio de Guadalupe durante los siglos XIV y XV (ca. 1330-1472). Hispania Sacra 64: 427-47. [CrossRef]

Díaz Martín, Luis Vicente. 1982. La consolidación de Guadalupe bajo Pedro I. En la Espana Medieval 2: 315-36.

Díaz Tena, Marí Eugenia. 2007. Los Milagros de Nuestra Señora de Guadalupe (siglo XV y Primordios del XVI): Edición y Estudio del Manuscrito C-1 del Archivo del Monasterio de Guadalupe. Mérida: Editorial Regional de Extramadura. 
Echevarría Arsuaga, Ana. 1999. The Fortress of Faith: The Attitude Towards Muslims in Fifteenth Century Spain. Leiden, Boston and Köln: Brill.

Echevarría Arsuaga, Ana. 2006. Caballeros en la Frontera: La Guardia Morisca de los Reyes de Castilla (1410-1467). Madrid: UNED.

Ernst, Carl. 1996. Rūzbihān al-Baqlī: Mysticism and the Rhethoric of Sainthood in Persian Sufism. Richmond: Curzon Press.

Fierro Bello, Maribel. 2002. Women as Prophets in Islam. In Writing the Feminine. Women in Arab Sources. Edited by Randi Deguilhem and Manuela Marín. London and New York: IB Tauris, pp. 183-98.

Filomena, Cerro Herranz María. 1983. La concesión de privilegios reales. El patrimonio de la Iglesia de Santa María de Guadalupe en el siglo XIV. Guadalupe 664: 125-27.

Fulton Brown, Rachel. 2019. Mary and the Art of Prayer: The Hours of the Virgin in Medieval Christian Life and Thought. New York: Columbia University Press.

García-Arenal, Mercedes. 2001. Dreams and reasons: Autobiographies of converts in religious polemics. In Conversions Islamiques. Identités Religieuses en Islam Mediterranéen. Edited by M. García-Arenal. Paris: Maisonneuve et Larose, pp. 89-118.

Garcías Palou, Sebastián. 1981. Ramón Llull y el Islam. Palma de Mallorca: Caja de Ahorros y Monte de Piedad.

Garrosa Resina, Antonio. 1987. Magia y Superstición en la Literatura Castellana Medieval. Valladolid: Universidad de Valladolid, Secretariado de Publicaciones.

Green, Nile. 2003. The Religious and Cultural Roles of Dreams and Visions in Islam. Journal of the Royal Asiatic Society 13: 287-313. [CrossRef]

Halligan, Fredrica R. 2001. The Creative Imagination of the Sufi Mystic, Ibn 'Arabi. Journal of Religion and Health 40: 275-87. [CrossRef]

Hames, Harvey J. 1999. Conversion via Ecstatic Experience in Ramon Llull's Llibre del gentil e dels tres savis. Viator 30: 181-200. [CrossRef]

Hatzfeld, Helmut. 1955. Estudios Literarios Sobre mística Española. Madrid: Credos.

Hess, Andrew C. 1978. The Forgotten Frontier. A History of the Sixteenth Century Ibero-African Frontier. London: Chicago University Press.

Highfield, Roger. 1983. The Jeronimites in Spain, Their Patrons and Successes. Journal of Ecclesiastical History 34: 513-33. [CrossRef]

Honerkamp, Kenneth L. 2005. Ibn 'Abbâd, modèle de la Shâdhiliyya. In Une voie Soufie dans le Monde: La Shâdhiliyya. Edited by Éric Geoffroy. Paris: Maisonneuve \& Larose, pp. 159-72.

Honerkamp, Kenneth L. 2009. Ibn'Abbad of Ronda. His Influence in Andalusia and Al-Magreb. In Historia del Sufismo en al-Andalus: Maestros Sufies de al-Andalus y el Magreb. Edited by Amina González Costa and Gracia López-Anguita. Córdoba: Almuzara, pp. 143-64.

Huygens, Robert B. C., and Jacques de Vitry. 1960. Lettres de Jacques de Vitry (1160/1170-1240). Leiden: Brill.

Ibn 'Arabi. 1980. The Bezel of Wisdom. Translated by R. W. Austin. Mahwah: Paulist Press.

Ibn 'Arabi. 2008. Sufis of Andalusia: The Ruh Al-Quds and Al-Durat Fakhirah. Translated by R. W. Austin. London: Routledge.

Jones, Linda G. 2003. Dreams and Visions: A Comparative Analysis of Spiritual Gifts in Medieval Christian and Muslim Conversion Narratives. In Medieval Cultures in Contact. Edited by Richard Gyug. New York: Fordham University Press, pp. 105-36.

Katz, Jonathan G. 1992. Visionary Experience, Autobiography, and Sainthood in North African Islam. Princeton Papers in Near East Studies 1: 85-118.

Katz, Jonathan G. 2012. Dreams and Their Interpretation in Sufi Thought and Practice. In Dreams and Visions in Islamic Societies. Edited by Ozgen Felek and Alexander D. Knysh. New York: State University of New York Press, pp. 181-98.

Knysh, Alexander D. 1999. Ibn 'Arabi in the Muslim West: A Prophet in His Own Land? In Ibn 'Arabi in the Later Islamic Tradition: The Making of a Polemical Image in Medieval Islam. New York: State University of New York Press, pp. 167-200.

Koet, Bart J. 2009. Divine Dreams Dilemmas: Biblical Visions and Dreams. In Dreaming in Christianity and Islam: Culture, Conflict, and Creativity. Edited by Kelly Bulkeley, Kate Adams and Patricia M. Davis. New Brunswick and London: Rutgers University Press, pp. 17-31.

Kruger, Steven F. 1992. Dreaming in the Middle Ages. Cambridge: Cambridge University Press. 
Kugle, Scott A. 2007. Sufis and Saints' Bodies: Mysticism, Corporeality, and Sacred Power in Islam. Chapel Hill: The University of North Carolina Press.

Lewis, Bernard, Charles Pellat, and Emeri Johannes Vandonzel, eds. 1978. Encyclopedia of Islam. Leiden: Brill, vol. 4.

Linehan, Peter. 1985. The Beginnings of Santa Maria de Guadalupe and the Fourteenth Century Direction of Castile. Journal of Ecclesiastical History 36: 284-304. [CrossRef]

Llopis Agelán, Enrique. 1998. Milagros, demandas y prosperidad: El monasterio Jerónimo de Guadalupe, 1389-1571. Revista de Historia Económica 16: 423-24.

López-Baralt, Luce. 1981. Simbología mística musulmana en San Juan de la Cruz y Santa Teresa de Jesús. Nueva Revista de Filología Hispánica 30: 54-55. [CrossRef]

Lugo Acevedo, Maria Luisa. 1999. La imagen luminica de Mahoma en el Libro de las Luces. In Actes du VIIIe Symposium International d'Études Morisques sur: Images des Morisques dans la Littérature et les Arts. Edited by Abdeljelil Temimi. Zaghouan: Fondation Temimi pour la Recherche Scientifique et l'Information, pp. 163-71.

Lynch, Margaret W. 2004. Stories, Saints, and Dreams: The Literary Uses of Dreams in Early Medieval Hagiography. Michigan: University of Michigan.

Maíllo Salgado, Felipe. 1992. Paralelismo e influencia entre el islam y el cristianismo: "Els cent noms de Deu" de Ramón Llull. Bulletin of the Faculty of Arts 54: 189-216.

Miller, Patricia C. 1994. Dreams in Late Antiquity. Princeton: Princeton University Press.

Montero, Ana M. 2010. The Vision of Heaven and Knowledge in Castilian Literature: From Alfonso X to Alfonso De La Torre. In Dreams and Visions: An Interdisciplinary Enquiry. Edited by Nancy van Deusen. Leiden and Boston: Brill, pp. 183-208.

Montoya Martínez, Jesús. 1981. Las colecciones de Milagros de la Virgen en la Edad Media: (el Milagro Literario). Granada: Universidad de Granada.

Moreira, Isabel. 2000. Dreams, Visions, and Spiritual Authority in Merovingian Gaul. Sage House: Cornell University Press.

Nader, Helen. 1979. The Mendoza Family in the Spanish Renaissance, 1350-1550. New Brunswick: Rutgers University Press.

Narváez Córdova, María Teresa. 2001. El despertar y el sueño: Dos motives místicos en un texto aljamiado. In Actes du IXe Symposium International d'études La Moriscologie: Orientation et Méthodologie. Edited by Abdeljelil Temimi. Zaghouan: Fondation Temimi pour la Recherche Scientifique et l'Information, pp. 117-24.

Ohlander, Erik S. 2012. Behind the Veil of the Unseen. Dreams and Dreaming in the Classical and Medieval Sufi Tradition. In Dreams and Visions in Islamic Societies. Edited by Ozgen Felek and Alexander D. Knysh. New York: State University of New York Press, pp. 199-214.

Pereda, Felipe. 2007. Las Imágenes de la Discordia: Política y Poética de la Imagen Sagrada en la España del Cuatrocientos. Madrid: Marcial Pons.

Pérez de Tudela, María Isabel. 1982. Alfonso XI y el Santuario de Santa María de Guadalupe. En la España Medieval 3: 271-85.

Pérez Priego, Miguel Ángel, and Marqués de Santillana. 1983. Poesías Completas II. Madrid: Alhambra.

Prado-Vilar, Francisco. 2005. The Gothic Anamorphic Gaze: Regarding the Worth of the Others. In Under the Influence. Questioning the Comparative in Medieval Castile. Edited by Cynthia Robinson and Leila Rouhi. Leiden: Brill, pp. 67-100.

Remensnyder, Amy G. 2014. La Conquistadora: The Virgin Mary at War and Peace in the Old and the New Worlds. New York: Oxford University Press.

Revuelta Somalo, José María. 1982. Los Jerónimos: Una Orden Religiosa Nacida en Guadalajara I: La Fundación (1373-1414). Guadalajara: Institución Provincial de Cultura Marqués de Santillana.

Robinson, Cynthia. 2011. Towers, Birds, and Divine Light: The Contested Territory of Nasrid and 'Mudéjar' Ornament. Medieval Encounters 17: 27-79. [CrossRef]

Robinson, Cynthia. 2013. Imagining the Passion in a Multiconfessional Castile: The Virgin, Christ, Devotions, and Images in the Fourteenth and Fifteenth Centuries. University Park: Pennsylvania State University Press.

Rodríguez, Gerardo. 2010. El Norte de África en Los Milagros de Guadalupe. Estudios de Historia de España 12: 447-65.

Rodríguez, Gerardo. 2013. La Corona de Castilla: Fronteras, milagros y confesionalización. Revista Signum 14: 234-49. [CrossRef] 
Roque, Maria-Àngels, ed. 2008. Ramon Llull Y El Islam: El Inicio Del Diálogo. Quaderns de la Mediterrània. Barrcelona: Instituto Europeo del Mediterráneo, vol. 9.

Rouhi, Leyla. 2005. A Fifteenth-Century Salamancan's Pursuit of Islamic Studies. In Under the Influence. Questioning the Comparative in Medieval Castile. Edited by Cynthia Robinson and Leila Rouhi. Leiden: Brill, pp. 67-100.

Rubio, Germán. 1926. Historia de Nuestra Señora de Guadalupe, o sea, Apuntes Históricos sobre el Origen, Desarrollo y Vicisitudes del Santuario y santa casa de Guadalupe. Barcelona: Industrias Gráficas Thomas.

Ruiz Hernando, José Antonio. 1997. Los Monasterios Jerónimos Españoles. Segovia: Caja Segovia.

Sánchez Herrero, José. 1989. Algunos elementos de la religiosidad cristiana popular andaluza durante la Edad Media. In La Religiosidad Popular. Edited by María Jesús Buxó Rey, Salvador Rodríguez Becerra and León Carlos Alvarez Santaló. Madrid: Anthropos, vol. 1, pp. 268-307.

Sánchez Sandoval, Juan José. 2004. Sufismo y Poder en Marruecos. Milagros de Abū-Yaczzà. Cádiz: Quorum Editores. Schleifer, Aliah. 1998. Mary the Blessed Virgin of Islam. Louisville: Fons Vitae.

Sirriyeh, Elizabeth. 2015. Dreams and Visions in the World of Islam: A History of Muslim Dreaming and Foreknowing. London: I.B. Tauris.

Sirry, Mun'im. 2010. Pious Muslims in the Making: A Closer Look at Narratives of Ascetic Conversion. Arabica 57: 437-54. [CrossRef]

Smilansky, Hagar K. 2008. Self-reflection and Conversion in Medieval Muslim Autobiographical Dreams. In Dreaming Across Boundaries: The Interpretation of Dreams in Islamic Lands. Edited by Louise Marlow. Cambridge: Harvard University Press, pp. 99-130.

Szpiech, Ryan. 2013. Conversion and Narrative: Reading and Religious Authority in Medieval Polemic. Philadelphia: Pennsylvania University Press.

Tolan, John V. 2002. Saracens: Islam in the Medieval European Imagination. New York: Columbia University Press.

Twomey, Lesley K. 2019. The Sacred Space of the Virgin Mary in Medieval Hispanic Literature: From Gonzalo de Berceo to Ambrosio Montesino. Woodbridge: Tamesis Books.

Urvoy, Dominique. 1980. Penser l'Islam: Les Présupposés Islamiques de l'“Art” de Lull”. Paris: Librairie Philosophique J. Vrin.

Vázquez, Miguel Ángel. 2016. Legitimación textual a través de los sueños: El caso del sueño del ṣālih de Túnez (ms. RESC/55 del CSIC). Al-Qantara: Revista de Estudios árabes 37: 233-68. [CrossRef]

Vizuete Mendoza, José Carlos. 1980. El patrimonio del monasterio de Santa María de Guadalupe (1340-1785). En la España medieval 1: 593-619.

Vizuete Mendoza, Juan Carlos. 1986. La biblioteca de Guadalupe: un reflejo de la espiritualidad jerónima. En La España Medieval 9: 1335-46.

Vizuete Mendoza, Juan Carlos. 1988. Guadalupe, un Monasterio Jerónimo (1389-1450). Madrid: Universidad Autónoma.

Wiegers, Gerard. 1994. Islamic Literature in Spanish and Aljamiado: Yça of Segovia (fl. 1450), His Antecedents and Successors. Leiden: Brill, vol. 8.

(C) 2019 by the author. Licensee MDPI, Basel, Switzerland. This article is an open access article distributed under the terms and conditions of the Creative Commons Attribution (CC BY) license (http://creativecommons.org/licenses/by/4.0/). 